\title{
Socio-Demographic Status and Self Rated Health Condition of the Elderly in Eastern Uttar Pradesh
}

\author{
Ankit Srivastava1, Pragya Singh ${ }^{2, *}$, Deepak Pandey ${ }^{3}$, Shikha Srivastava ${ }^{4}$, Syed Neyaz Hasan $^{5}$ \\ ${ }^{1}$ Department of Anatomy, Government Medical College, Azamgarh, Uttar Pradesh, INDIA. \\ ${ }^{2}$ Department of Food and Nutrition, Institute of Home Economics, University of Delhi, New Delhi, INDIA. \\ ${ }^{3}$ Department of Paediatrics, Government Medical College, Azamgarh, Uttar Pradesh, INDIA. \\ ${ }^{4}$ Department of Community Medicine, Govt. Medical College, Azamgarh, Uttar Pradesh, INDIA. \\ ${ }^{5}$ Department of Physiology, Govt. Medical College, Azamgarh, Uttar Pradesh, INDIA.
}

\begin{abstract}
Background: The increasing number of the elderly persons and their health problems has greater implications on public health programs in developing countries. Estimates of health problems of elderly are required from time to time to predict trends in disease burden and to further plan health care for them. Therefore, this study was conducted to determine the prevalent diseases and places for seeking treatment among the elderly in eastern uttar Pradesh. Materials and Methods: A community based cross sectional study was carried out for the elderly people and the information was collected in pre tested instrument. Using multistage stratified random sampling procedure, a total 417 elderly respondents were participated in the study. Information was sought on the respondent's socio-demographic characteristics and self-reported disease suffering by the elderly. Results: Maximum numbers of diseased case were among females (38.06\%) than males (26.45\%).Breathing problem was found one of the major problem among each sex of the elderly. It was found that more than half of the elderly suffering from more than one disease. Conclusion: Breathing problem and joint problems were prevalent in both male and female elderly population. Social status and age of the elderly play important role in seeking treatment from the private/government health care facilities
\end{abstract}

Key words: Elderly health problem, Eastern Uttar Pradesh, Self rated health condition, Geriatric depression scale, Psychological factor.

\begin{tabular}{r} 
Article Information \\
\hline Received: 01-05-2021 \\
Revised : 12-06-2021 \\
Accepted: $15-07-2021$ \\
\hline Correspondence \\
Dr. Pragya Singh \\
Assistant Professor, Department of Food \\
and Nutrition, Institute of Home Economics, \\
University of Delhi, New Delhi, INDIA. \\
Phone: +91-8800765908. \\
E-mail: pragya.singh@ihe.du.ac.in
\end{tabular}

\section{INTRODUCTION}

Health is the single most important determinant of the quality of life among elderly. The health status of the elderly is determined by a host of economic, social, psychological and physiological factors. With advancing age, ill-health becomes a major hindrance for the well-being of the elderly. Therefore, not only physical but even perceived health is an important predictor for

\begin{tabular}{|l|r|}
\hline \multicolumn{2}{|c|}{ Access this article online } \\
\hline $\begin{array}{l}\text { Website: } \\
\text { www.jcramonline.com }\end{array}$ & Quick Response code \\
\hline DOI: & \\
10.5530/jcram.1.1.4 & \\
& \\
\hline
\end{tabular}

their living happily. ${ }^{1}$ A number of studies have found that self-rated general health condition among the elderly is a valid measure of their health status. ${ }^{2}$ The selfrating of health is influenced largely by physical health conditions like chronic diseases, functional disability, sensory performance, the number of sick days, etc. Moreover, not only the objective health condition but also the psychological and social factors influence the self-rating of health. ${ }^{3}$ Contrary to the subjective nature of rating one's own health, the assessment of mental health and functionality can be done with more objectivity due to the methodology available for understanding the mental and functional health status. The elderly with good mental and physical health are expected to be healthier than their counterparts.

In India, the family is the great single source of support and center of activity for most elderly people, but the 
decrease in the number of children, their dispersion owing to migration and urbanization reduced the care of dependent old parents. The elders need certain amenities such as health care, nutrition and a sense of belonging. But the type and amount of treatment they receive mainly depend on the culture of the family. Usually, elder people are neglected by the family members unless they are well-to-do or still earning members. ${ }^{4-6}$ Low social and economic status, high rate of illiteracy and a general lack of basic amenities constitute major problems for the elder persons, particularly in rural areas. Life becomes increasingly stressful during the ageing process and elder people become a liability, rather than an asset, for the families and communities involved. ${ }^{6}$ In society the quality of relationship with sons and daughters largely decide the economic factors, which, in turn, determine the health of the elderly people.

A number of gerontological studies have discussed the relationships among morbidity or health status, age, gender and marital status of elders, but no universal pattern has been established so far. For example, an increased morbidity with increased age, but greater among men than women and more among rich people than poor, ${ }^{7}$ no consistent increase in morbidity with age, ${ }^{8}$ increased morbidity with increased age and more among female in the beginning of ageing, increased prevalence of chronic morbidity with increased age of elderly people and more among women than men ${ }^{9}$ and an increased survival of currently married elderly or living with their sons or daughters. ${ }^{10}$ When the elderly engage themselves in any economic activity and they possess assets, it provides a sense of security to them. Their engagement with economy produced good physical and mental constancy in them which plays an important role in their older time.

\section{MATERIALS AND METHODS}

\section{Sampling Procedure and Sample Size Formula}

A multistage sampling method was used to select the sample for the study. Though care was taken to avoid investigator bias in selecting the sample for the study by using a random sample, 60 years and above 60 years, each respondent on selected villages was approached during data collection. In this manner, a list with a total of 410 elderly was enumerated from all the four districts in eastern Uttar Pradesh. The required number of sample households would be

$$
\mathrm{n}_{\mathrm{h}}=\mathrm{m} \times \mathrm{n}=\mathrm{m} \times\left\{\mathrm{p}(1-\mathrm{p})\left(\mathrm{z}^{2} / \mathrm{e}^{2}\right) \times f\right\}
$$

where $\mathrm{n}$ is the required sample size for elderly having solitary living; $\mathrm{m}$ is the required number of households to get at least one such elderly;

$\mathrm{p}$ is the proportion of elderly living alone; $\mathrm{z}$ is 1.96 ( $\mathrm{z}$ value at 5\% level of significance); e is 0.05 (amount of admissible error); $f$ is 1.5 (assumed design effect).

Thus, as an approximation, suppose that about $6 \%$ of the elderly live alone in rural areas (Central Region, NFHS-3), then

$$
\mathrm{n}=\mathrm{p}(1-\mathrm{p})(\mathrm{z} 2 / \mathrm{e} 2) \times \mathrm{f}=86.68 \times 1.5=130 \text { (approx.) }
$$

In order to ensure separate estimates based on location (districts with low, medium, and high composite index), at least three estimates will be needed. Thus, the required minimum sample size will be $130 \times 3=390$. The sample has to increase by $5 \%$ to account for contingencies, such as non-response or recording error. $\mathrm{n}+5 \%=390 \times 1.05=409.5 \sim 410$ As per government reports (census, NFHS), from three households in a village of eastern Uttar Pradesh, one can get at least one elderly person. Thus, $\mathrm{nh}=410 \times 3=1,230$ households Therefore, 1,230 households had chosen from the rural areas to get the required number of elderly in the sample.

Chi-square is carried out to study the relationships of several socio-economic, demographic and cultural factors on the health status of elderly. Explanatory factors are taken on both household and individual (elderly) levels. The analysis is carried out in likelihood association of the dependent variable (health status of elderly) is examined across various socio-economic, demographic and cultural explanatory variables through chi-square test statistic. Regression analysis is carried out to study the relationships of several socioeconomic, demographic and cultural factors on the health status and well-being of the elderly. Explanatory factors are taken on both household and individual (elderly) levels.

\section{AIM AND OBJECTIVES}

The aim is to study the status of elderly particularly their health position and factors affecting therein. The objective of this paper to perceive health status and overall well-being of elderly people and the factors that affects them.

\section{RESULTS AND DISCUSSION}

Following results were obtained.

Above Table 1 shows that the elderly belonging to male and female are 68.29 and 31.71 percent respectively in 
Table 1: Percentage distribution of the elderly according to their demographic and socio-economic characteristics.

\begin{tabular}{|c|c|c|}
\hline Variables & $\mathbf{N}$ & Percentage \\
\hline \multicolumn{3}{|c|}{ Gender } \\
\hline Male & 280 & 68.29 \\
\hline Female & 130 & 31.71 \\
\hline \multicolumn{3}{|c|}{ Age } \\
\hline $60-69$ & 257 & 62.68 \\
\hline $70-79$ & 116 & 28.29 \\
\hline 80 and above & 37 & 9.02 \\
\hline \multicolumn{3}{|c|}{ Marital status } \\
\hline Unmarried & 08 & 1.95 \\
\hline Currently Married & 238 & 58.05 \\
\hline Widow & 102 & 24.88 \\
\hline Widower & 62 & 15.12 \\
\hline \multicolumn{3}{|l|}{ Caste } \\
\hline General & 183 & 44.63 \\
\hline ОВС & 126 & 30.73 \\
\hline SC/ST & 101 & 24.63 \\
\hline \multicolumn{3}{|c|}{ Educational status } \\
\hline Illiterate & 217 & 52.93 \\
\hline Primary & 59 & 14.39 \\
\hline Secondary & 65 & 15.85 \\
\hline High School & 33 & 8.05 \\
\hline Intermediate & 15 & 3.66 \\
\hline Graduate and above & 21 & 5.12 \\
\hline \multicolumn{3}{|c|}{ Present occupation } \\
\hline Agriculture & 61 & 14.88 \\
\hline Agriculture laborer & 79 & 19.27 \\
\hline Industrial Laborer & 13 & 3.17 \\
\hline Service & 20 & 4.88 \\
\hline Business & 11 & 2.68 \\
\hline Nothing/Other & 226 & 55.12 \\
\hline \multicolumn{3}{|c|}{ Occupation prior 60 years of age } \\
\hline Agriculture & 116 & 28.29 \\
\hline Agriculture laborer & 120 & 29.27 \\
\hline Industrial Laborer & 22 & 5.37 \\
\hline Service & 61 & 8.05 \\
\hline Business & 29 & 7.07 \\
\hline Nothing/Other & 62 & 10.00 \\
\hline Total & 410 & 100.00 \\
\hline
\end{tabular}

the study area. About 63 percent of elderly belong to age group 60-69, 28.29 percent group 70-79 and 9.02 percent age $80^{+}$.Only 1.95 percent unmarried, 58.05 percent currently married, 24.88 percent widow and 15.12 percent widower. About forty five percent of surveyed households belong to General categories, 30.73 percent of other backward classes and 24.63 percent to SC/ST castes.

About 53 percent of elderly in surveyed area are illiterate, 14.39 percent primary class, 15.85 secondary, 8.05 high school, 3.66 intermediate and only 5.12 percent graduate and above. Majority of survey household
Table 2: Distribution of elderly on the basis of mental health status by type of background characteristics

\begin{tabular}{|c|c|c|c|c|}
\hline \multirow{2}{*}{$\begin{array}{c}\text { Background } \\
\text { Characteristics }\end{array}$} & \multicolumn{3}{|c|}{ Geriatric Depression Scale } & \multirow[t]{2}{*}{$x^{2}$ value } \\
\hline & Normal & Mild & Severe & \\
\hline \multicolumn{5}{|c|}{ AGE GROUP } \\
\hline $60-69$ & $85(33.07)$ & $92(35.80)$ & $80(31.13)$ & \multirow{3}{*}{$\begin{array}{l}16.81 \\
0.002\end{array}$} \\
\hline $70-79$ & $23(19.83)$ & $42(36.21)$ & $51(43.97)$ & \\
\hline $80+$ & $03(8.11)$ & $15(40.54)$ & $19(51.35)$ & \\
\hline \multicolumn{5}{|c|}{ GENDER } \\
\hline Male & $94(35.57)$ & $107(38.21)$ & $79(28.21)$ & \multirow{2}{*}{$\begin{array}{l}31.54 \\
0.000\end{array}$} \\
\hline Female & $17(13.08)$ & $42(32.31)$ & $71(54.62)$ & \\
\hline \multicolumn{5}{|c|}{ CASTE } \\
\hline SC/ST & $21(20.79)$ & $33(32.67)$ & $47(46.53)$ & \multirow{3}{*}{$\begin{array}{l}7.35 \\
0.119\end{array}$} \\
\hline овС & $37(29.37)$ & $43(34.13)$ & $46(36.51)$ & \\
\hline General & $53(28.96)$ & 73(39.89) & $57(31.15)$ & \\
\hline \multicolumn{5}{|c|}{ Type of Family } \\
\hline Nuclear & $17(14.17)$ & $40(33.33)$ & $63(52.50)$ & \multirow{2}{*}{$\begin{array}{l}22.61 \\
0.000\end{array}$} \\
\hline Joint & $94(32.41)$ & 109(37.79) & $87(30.00)$ & \\
\hline \multicolumn{5}{|c|}{ Marital Status } \\
\hline Other & $14(8.14)$ & $65(37.79)$ & $93(54.07)$ & \multirow{2}{*}{$\begin{array}{l}64.16 \\
0.000\end{array}$} \\
\hline Currently Married & $97(40.76)$ & $84(35.29)$ & $57(23.95)$ & \\
\hline \multicolumn{5}{|c|}{ Type of Cards } \\
\hline BPL & $26(29.55)$ & $28(31.82)$ & $34(38.64)$ & \multirow{2}{*}{$\begin{array}{l}1.01 \\
0.603\end{array}$} \\
\hline Other & $85(26.40)$ & $121(37.58)$ & $116(36.02)$ & \\
\hline \multicolumn{5}{|c|}{ Social Status } \\
\hline Low & $72(25.62)$ & $94(33.45)$ & $115(40.93)$ & \multirow{3}{*}{$\begin{array}{l}11.56 \\
0.032\end{array}$} \\
\hline Medium & $28(26.92)$ & $47(45.19)$ & $29(27.88)$ & \\
\hline High & $11(44.00)$ & $8(32.00)$ & $6(24.00)$ & \\
\hline \multicolumn{5}{|c|}{ Economic Status } \\
\hline Poor & $38(27.94)$ & $39(28.68)$ & $59(43.38)$ & \multirow{4}{*}{$\begin{array}{l}10.57 \\
0.032\end{array}$} \\
\hline Middle & $28(22.95)$ & $45(36.89)$ & $49(40.16)$ & \\
\hline Rich & $45(29.61)$ & $65(42.79)$ & $42(27.63)$ & \\
\hline Total & & & & \\
\hline
\end{tabular}

57.56 in selected area main occupation is agriculture and agriculture labor, about $20 \%$ of elderly based on salary (industrial labor, government job and private services), 7.07 percent reported that they have small business and only 3.90 women reporting that they have only 3.90 woman reporting that they have only do kitchen work. 10.00 percent elderly reported that they have do not do anything.

The present study also tries to capture the psychosomatic status of elderly by measuring the level of depression status. In the geriatric depression, scale questions are answered "Yes" and "No". The GDS is commonly used as a routine part of the comprehensive geriatric assessment. One point is assigned to each answer and the cumulative score is rated on a scoring 
grid. The grid sets a range of 0-9 as "Normal", 10-19 as "mildly depressed", and 20-30 as "severely depressed". The level of depression among elderly has been measured on the basis of 30 point scale. Elderly giving response between 20 to 30 statements scored has been rated as a patient of severely depressed and 10 to 19 statements scored has been rated as a patient of mild depressed state. Elderly scoring 0 to 9 statements were rated as normal. The result seems to alarm as about 42 percent elderly were suffering from severe depression and 37 percent of mild depression. The above result shows that the percent of severely depressed patient increase with increase in their age. (Table 2)

About 31 percent severely depressed patient were in the age group 60-69, 44 percent in the age group 70-79 and maximum 52 percent aged above 80 . In SC/ST category there were more severely depressed elderly when compared to OBC and general category elderly. Also more depressed elderly were part of nuclear family when compared to Joint family. More elderly other than presently married category (Alone, Widow / Widower) were found suffering from severe depression. About 24.00 percent of elder low social status reported that they were suffering from severe depression, 32.00 percent mild and 24.00 percent from normal. About 28.00 percent of elder poor economic status reported that they suffering from severe depression, 43.00 percent mild and 30.00 percent from normal. The mental health and age, gender, type of family, marital status is highly associated $(p<0.01)$. The association between mental health and social status, economic status gender, type of family, marital status is associated $(p<0.05)$. Above results show that no association between caste and type of cards with mental health. (Table 2)

\section{Self-rated health condition}

The self-rated health is considered as a strong predictor to understand the health status of people in general and the elder people in particular. The self-rated health was assessed in the research using two different measures - current health condition and health condition in comparison to previous year. The all elderly respondent rated their current health status on five points - (i) Excellent (ii) Very good (iii) Good (iv) Fair (v) Bad. Similarly all elder all respondents rate their health rate status is compared to the previous year. This scale is divided in three category-(i) Better (ii) Same (iii) Worse

19.64 per cent of the male elderly reported that their health condition has worsened in comparison to the previous year while 20.77 per cent female elderly said their situation has worsened. Moreover, health condition compared to previous year of elder was found not significantly associated with Gender $\left(\chi^{2}=0.81 ; \mathrm{d} f=2\right)$.

The survey found that 15.95 percent of the elderly among the age group of 60-69 reported that their health condition has worsen when compared to the previous year. 28.45 percent and 21.62 percent of them reported that their health condition has worsened when compared to the previous year among the age group of 70-79 and above 80 years respectively. Thus the health status compared to previous year of elderly was found associated with the age $(\chi 2=10.38, \mathrm{~d} f .=4)$ an increased bad health condition was reported with increased age of the elderly people.

18.07 percent of currently married elderly reported that their condition has worsened in comparison to 22.67 percent of other category of the elderly. However, the condition of health compared to previous year was not found associated with marital status of the elderly $(\chi 2=1.35 ; \mathrm{d} f .=2)$.

When comparing the current health condition in the caste category it was found that 19.67 percent in general category, 22.22 percent $\mathrm{OBC}$ category and 17.82 percent SC/ST category reported that their health condition has worsened. Caste was not found significantly related with the health status of elderly in caste of the study $(\chi 2=2.72 \mathrm{~d} f .=4)$

Currently working elderly reported that their health condition compare to previous year is more better than the condition of the category (nothing/other) who has not doing anything. However, the condition of health compared to previous year was found associated with present occupation of the elderly $(\chi 2=22.24 ; \mathrm{d} f=6)$.

19.93 per cent low status category of the elderly, 19.23 per cent middle social status elderly and 24.00 per cent of High Social status elderly reported that their condition has worsened when compared to the previous year. 23.44 percent of the elderly belongs to low economic status category, 15.32 percent of the elderly in middle economic category and 17.78 percent of the elderly in high economic status category reported that their condition has worsened when compared to the previous year. Nevertheless, statistically not significant association was found between the health condition of elderly and social status of their households $(\chi 2=2.54 ; \mathrm{d} f=4)$. More or less a similar pattern was observed between economic status of the households and health status of the elder but it's not statistically significant $(\chi 2=5.99 ; \mathrm{d} f .=4)$.

When comparing the health condition in living arrangement category it was found that 31.25 percent 
Table 3: Self rated current health condition compared to previous to previous year the elderly with background characteristics.

\begin{tabular}{|c|c|c|c|c|}
\hline \multirow{2}{*}{$\begin{array}{l}\text { Background } \\
\text { characteristics }\end{array}$} & \multicolumn{3}{|c|}{ Comparative Health Condition } & \multirow[t]{2}{*}{$\chi^{2}$ Value } \\
\hline & $\begin{array}{l}\text { Better } \\
\text { than } \\
\text { previous } \\
\text { year }\end{array}$ & $\begin{array}{l}\text { Same as } \\
\text { previous } \\
\text { year }\end{array}$ & $\begin{array}{l}\text { Worse } \\
\text { than } \\
\text { previous } \\
\text { year }\end{array}$ & \\
\hline \multicolumn{5}{|c|}{ Gender } \\
\hline Male & $14(5.00)$ & $211(75.36)$ & $55(19.64)$ & \multirow{2}{*}{$\begin{array}{l}0.81 \\
d_{f}=2\end{array}$} \\
\hline Female & 04(3.08) & $99(76.15)$ & $27(20.77)$ & \\
\hline \multicolumn{5}{|l|}{ Age } \\
\hline $60-69$ & $15(5.84)$ & $201(78.21)$ & $41(15.95)$ & \multirow{3}{*}{$\begin{array}{c}10.38^{*} \\
d_{f}=4\end{array}$} \\
\hline $70-79$ & $2(1.72)$ & $81(69.83)$ & $33(28.45)$ & \\
\hline $80+$ & $1(2.70)$ & $28(75.68)$ & $8(21.62)$ & \\
\hline \multicolumn{5}{|c|}{ Marital Status } \\
\hline Others & $7(4.07)$ & $126(73.26)$ & $39(22.67)$ & \multirow{2}{*}{$\begin{array}{l}1.35 \\
d_{f}=2\end{array}$} \\
\hline $\begin{array}{l}\text { Currently } \\
\text { Married }\end{array}$ & $11(4.62)$ & 184(77.31) & $43(18.07)$ & \\
\hline \multicolumn{5}{|l|}{ Caste } \\
\hline SC/ST & $7(6.93)$ & $76(75.25)$ & $18(17.82)$ & \multirow{3}{*}{$\begin{array}{l}2.72 \\
d_{f}=4\end{array}$} \\
\hline OBC & $5(3.97)$ & $93(73.81)$ & $28(22.22)$ & \\
\hline General & $6(3.28)$ & $141(77.05)$ & $36(19.67)$ & \\
\hline \multicolumn{5}{|c|}{ Present occupation $^{+}$} \\
\hline Agriculture & $4(6.56)$ & $52(85.25)$ & $5(8.20)$ & \multirow{6}{*}{$\begin{array}{c}22.24^{* * *} \\
d_{f}=6\end{array}$} \\
\hline $\begin{array}{l}\text { Agriculture } \\
\text { Labor }\end{array}$ & $5(6.33)$ & $63(79.75)$ & 11(13.92) & \\
\hline Industrial labor & $0(0.00)$ & $11(84.62)$ & $2(15.38)$ & \\
\hline Services & $2(10.00)$ & $17(85.00)$ & $1(5.00)$ & \\
\hline Business & $0(0.00)$ & $11(100.00)$ & $0(0.00)$ & \\
\hline Nothing/Other & $7(3.10)$ & $156(69.03)$ & $63(27.88)$ & \\
\hline \multicolumn{5}{|c|}{ Social Status } \\
\hline Low & $15(5.34)$ & $210(74.73)$ & $56(19.93)$ & \multirow{3}{*}{$\begin{array}{l}2.54 \\
d_{f}=4\end{array}$} \\
\hline Middle & $3(2.88)$ & $81(77.88)$ & $20(19.23)$ & \\
\hline High & $0(0.00)$ & $19(76.00)$ & $6(24.00)$ & \\
\hline \multicolumn{5}{|c|}{ Economic Status } \\
\hline Low & $6(2.87)$ & $154(73.68)$ & $49(23.44)$ & \multirow{3}{*}{$\begin{array}{l}5.99 \\
d_{f}=4\end{array}$} \\
\hline Middle & $8(7.21)$ & $86(77.48)$ & $17(15.32)$ & \\
\hline High & $4(4.44)$ & $70(77.78)$ & $16(17.78)$ & \\
\hline \multicolumn{5}{|c|}{ Separate room } \\
\hline Yes & $10(5.95)$ & $122(72.61)$ & $36(21.42)$ & \multirow{2}{*}{$\begin{array}{l}2.21 \\
d_{f}=2\end{array}$} \\
\hline No & $8(3.30)$ & 188(77.69) & 4619.01) & \\
\hline \multicolumn{5}{|c|}{ Current living arrangement $^{++}$} \\
\hline Alone & $0(0.00)$ & $11(68.75)$ & $5(31.25)$ & \multirow{3}{*}{$\begin{array}{l}2.72 \\
d_{f}=4\end{array}$} \\
\hline With spouse & 2(9.52) & $15(71.43)$ & $4(19.05)$ & \\
\hline $\begin{array}{l}\text { With spouse } \\
\text { and adult } \\
\text { children }\end{array}$ & $5(2.63)$ & $156(82.11)$ & $29(15.26)$ & \\
\hline $\begin{array}{l}\text { With adult } \\
\text { children }\end{array}$ & $5(3.79)$ & $96(72.73)$ & $31(23.48)$ & \\
\hline $\begin{array}{l}\text { With other } \\
\text { relative }\end{array}$ & $6(11.76)$ & $32(62.75)$ & $13(25.49)$ & \\
\hline Total & $18(4.39)$ & $310(75.61)$ & $82(20.00)$ & $410(100.0)$ \\
\hline
\end{tabular}

Note: $+\chi 2$ value calculated by labour and business $++\chi 2$ value calculated by merging the health condition better and same one category

Figures in parentheses represent the percentage.

$* p<0.05 ; * * *<<0.001$ of elderly living alone, 19.05 percent of the elderly living with spouse, 15.26 percent with spouse and adult children and 23.48 percent of the elderly living with their son and 18.00 percent of other category elderly reported that their health condition has worsened. No statistically significant association was found between the health condition compared to elderly and intergenerational living arrangement of the elderly $(\chi 2$ $=2.72 ; \mathrm{d} f=4)$. (Table 3$)$

In general, the study found that satisfaction of selfrated health among the elderly in the country is significantly lower than the overall population as well as the elderly in developed countries. A majority of the elderly reported that their current health condition in more or less the same as that with their condition of health one year earlier. This signifies the poor health condition existing in the country. There are also significant socio-economic gradients in self-rated health with poor, age above 80 yrs. Female, other, not working SC/ST, illiterate, middle social status and middle economic status rating health much worse their counter parts.

It was found that about 37 per cent males and 45 per cent female elderly belonged to bad health condition. Moreover, health status of elderly was found not significantly associated with $\operatorname{sex}\left(\chi^{2}=2.52 ; \mathrm{d} f=1\right)$ and the prevalence of bad health condition was found more among females than male elderly. An age wise health status of elderly indicates that about 35,46 and 51 per cent elderly of 60-69, 70-79 and 80+ years age groups respectively had bad health. Thus the health status of elderly was found associated with the age $\left(\chi^{2}=6.72\right.$; $\mathrm{d} f .=2)$ an increased bad health condition was reported with increased age of the elderly people. (Table 4)

Impact of education cannot be ignored in assessing and measuring the health status of elderly people because an adequate educational attainment is related to an 'acceptable' social behavior. About 45 per cent elderly belonging to illiterate possessed had bad health, whereas only 34 per cent elderly having education up to high school or above possessed bad health. However, no significant association was observed between education and health status of elderly $\left(\chi^{2}=4.71 ; \mathrm{d} f=1\right)$ So far the condition of health status of elderly people according to marital status is concerned; it was found that the health status of currently married elderly was better as compared to widow/widower or singles. (Table 4)

About 35 per cent elderly who were currently married possessed bad health, while more than this about 46 per cent widows or widowers were in bad health condition. 
Table 4: Distribution of elderly on the basis of their health status and background variables.

\begin{tabular}{|c|c|c|c|c|}
\hline Background & Good & Bad & Total & $\mathrm{x} 2$ value \\
\hline \multicolumn{5}{|c|}{ Gender } \\
\hline Male & $176(62.86)$ & $104(37.14)$ & 280 & 2.52 \\
\hline Female & $71(54.62)$ & $59(45.38)$ & 130 & 0.113 \\
\hline \multicolumn{5}{|c|}{ Age Group } \\
\hline $60-69$ & $167(64.98)$ & $90(35.02)$ & 257 & \\
\hline $70-79$ & $62(53.45)$ & $54(46.55)$ & 116 & 6.72 \\
\hline $80+$ & $18(48.65)$ & $19(51.35)$ & 37 & 0.035 \\
\hline \multicolumn{5}{|c|}{ Educational Status } \\
\hline Illiterate & $120(55.30)$ & $97(44.70)$ & 217 & 4.705 \\
\hline Literate & $127(65.80)$ & $66(34.20)$ & 193 & 0.03 \\
\hline \multicolumn{5}{|c|}{ Marital Status } \\
\hline Others & $93(54.07)$ & $79(45.93)$ & 172 & \\
\hline Current & & & & 4.72 \\
\hline Married & $154(64.71)$ & $84(35.29)$ & 238 & 0.03 \\
\hline \multicolumn{5}{|c|}{ Type of work } \\
\hline Agriculture & $47(77.05)$ & $14(22.95)$ & 61 & \\
\hline Labor & $67(65.05)$ & $36(34.95)$ & 103 & \\
\hline Services & 19(95.00) & $1(5.00)$ & 20 & 27.34 \\
\hline Others & $114(50.44)$ & $112(49.56)$ & 226 & 0.00 \\
\hline \multicolumn{5}{|c|}{ Economic Status } \\
\hline Low & $159(56.58)$ & $122(43.42)$ & 281 & \\
\hline Middle & $70(67.31)$ & $34(32.69)$ & 104 & 5.24 \\
\hline High & $18(72.00)$ & $7(28.00)$ & 25 & 0.15 \\
\hline \multicolumn{5}{|c|}{ Social Status } \\
\hline Low & $72(52.94)$ & $64(47.06)$ & 136 & \\
\hline Middle & $67(54.92)$ & $55(45.08)$ & 122 & 11.89 \\
\hline High & $108(71.05)$ & $44(28.95)$ & 152 & 0.003 \\
\hline \multicolumn{5}{|c|}{ Type of Family } \\
\hline Nuclear & $60(50.00)$ & $60(50.00)$ & 120 & 7.43 \\
\hline Joint & $187(64.48)$ & $103(35.52)$ & 290 & 0.006 \\
\hline \multicolumn{5}{|c|}{ Social Category } \\
\hline SC/ST & $50(49.50)$ & $51(50.50)$ & 101 & \\
\hline OBC & $91(72.22)$ & $35(27.78)$ & 126 & 12.82 \\
\hline General & $106(57.92)$ & $77(42.08)$ & 183 & 0.002 \\
\hline \multicolumn{5}{|c|}{ Type Of house } \\
\hline Kuccha & $31(47.69)$ & $34(52.31)$ & 65 & \\
\hline Semi Pucca & $64(58.72)$ & $45(41.28)$ & 109 & 6.089 \\
\hline Pucca & $152(64.41)$ & $84(35.59)$ & 236 & 0.048 \\
\hline \multicolumn{5}{|c|}{ Number Of Family Member } \\
\hline One & $5(50.00)$ & $5(50.00)$ & 10 & \\
\hline Two & $11(44.00)$ & $14(56.00)$ & 25 & \\
\hline Three & $4(30.77)$ & $9(69.23)$ & 13 & \\
\hline Four & $16(72.73)$ & $6(27.27)$ & 22 & \\
\hline Five to & & & & 10.23 \\
\hline Seven & $91(64.08)$ & $51(35.92)$ & 142 & 0.069 \\
\hline \multicolumn{5}{|l|}{ More than } \\
\hline Seven & $120(60.61)$ & 78(39.39) & 198 & \\
\hline
\end{tabular}

However, the status of health was not found associated with marital status of the elderly $\left(\chi^{2}=4.72 ; \mathrm{d} f=1\right)$. (Table 4)

As mentioned elsewhere, caste plays an important role in socio-economic and cultural stratification of society in India by classifying people in endogamous groups with each group having a common surname. Caste is hereditary trait and it largely determines the function, status, opportunities available for advancement in life, and the handicaps and obstacles towards greater vertical mobility. It also determines the differences in cultural patterns and practices. The caste system in India still dominates her cultural life, particularly in the rural areas. Compared to the Lower caste families, the family behaviour of upper castes toward their elderly persons is usually found better. ${ }^{11} 42$ and 28 per cent elderly belonging to General and OBC caste groups had good health status. It is interesting to note that the elderly of schedule caste and schedule tribe, who are supposed to be more deprived, about 50 per cent had bad health. Nevertheless, caste was found significantly related with the health status of elderly in caste of the study $\left(\chi^{2}=12.82 ; \mathrm{d} f=3\right)$. Significant association was observed between Caste and health status of the elderly.

It has been seen that the health status of family members of a household is found, to some extent, dependent on socio-economic status of the household. This sample study reports that about 47,45 and 29 per cent elderly who belonged respectively to low, middle and high social status group of the households possessed bad health. Nevertheless, statistically significant association was found between the health status of elderly and social status of their households $\left(\chi^{2}=11.89\right.$; $\mathrm{d} f=2)$. More or less a similar pattern was observed between economic status of the households and health status of the elderly but its not statistically significant $\left(\chi^{2}=6.3 ; \mathrm{d} f=2\right)$. About 43,33 and 28 per cent elderly belonging to low, middle and high economic status of households respectively possessed bad health. Less percentage of elderly having bad health in low social and economic groups of the households may be that people of this category being economically weak mostly involved

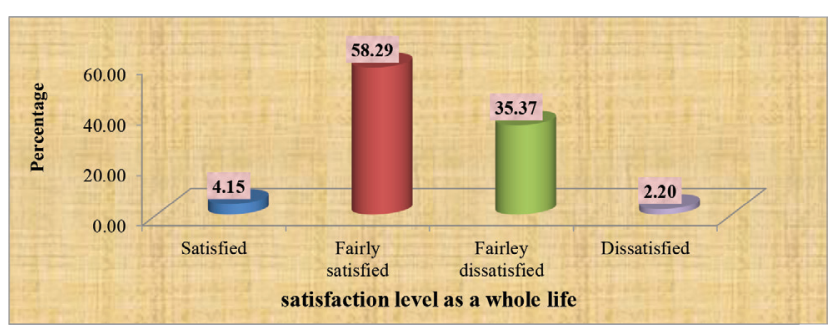

Figure 1: Self rated satisfaction level as a whole life. 
in manual works for their survival do not report of a disease unless it becomes more serious or unbearable.

Satisfaction is the ultimate goal of everybody's life. Our every effort seeks to the happiness and satisfaction. In our life we proceed toward job, education and other profession to require our ultimate got children youth and old people got this goal by different function. (Figure 1) Particularly the elders need this satisfaction in their old age. The presented graph rectifies the ratio of the satisfaction concerning to satisfied, fairly satisfied and dissatisfied. The data represents that out of whole life as $100 \%, 4.15 \%$ elderly, were fully satisfied in their old age. 58.29\% elderly were fairly satisfied and 35.37\% were fairly dissatisfied and finally $2.20 \%$ were unsatisfied with the amenities of their old age.

\section{CONCLUSION}

It was found in the study that females' current health condition was twice bad as compared to males. The current health condition of elderly was bad between the age group of 70-79. The current health condition of currently married elderly was found less bad as compared to the other than currently married. Moreover, it was found that most bad current health condition was of SC/ST elderly. It was also found in the study that economic condition is directly associated with current health condition of elderly, as the former increased the latter became better.

In addition to this the current health condition of elderly compared to previous year was also evaluated. It was self-rated by the elderly of 70-79 age group that their current health condition as compared to previous year was worst. The elderly belonging to low economic status reported that their current health condition was worst when compared to previous year.

The study evaluates the self-rated mental health conditions of the elderly. It was found that the mental health conditions of females were not good and they faced depression. On other hand males were less depressed. The currently married elderly were found to be less depressed as compared to the other than currently married. Moreover, it was found that SC/STs were more depressed when compared to other than SC/STs. The study highlights that the participation in work affects the mental health conditions of the elderly in positive way, as more they worked less was the chance of depression. The living conditions also affected the mental health conditions of the elderly. If separate rooms for sleeping are available, elderly people were found to be less depressed. The elderly who were less comfortable in their present living conditions were more depressed. The current living arrangement of the elderly who were living with spouse and adult children were found to be less depressed as compared to others. Moreover, it was found that elderly who were fully dependent on their children were more depressed when compared to others. It was also found that if the relationship of the elderly was good with their children they were less depressed.

The morbidity pattern and treatment places of the elderly were evaluated. The main morbidities found in the elderly are joint problems, neuro problems, cardio problems, eye and ENT, sugar and BP problems, breathing problems and gastro-intestinal. Joint and breathing problems were the found to be major morbidities of the elderly in the study area. The vast population of our country is making it difficult for elderly people to get treatment in govt. hospitals. Moreover, the facilities are not satisfactory and able fulfill the health needs of such a vast population.

Satisfaction is the ultimate goal of everybody's life. Our every effort seeks to the happiness and satisfaction. In our life we proceed towards job, education and other professions to achieve this satisfaction. Particularly the elders need this satisfaction in their old age.

\section{REFERENCES}

1. Kivinen P, Halonen P, Eronen M, Nissinen A. Self-rated health, physicianrated health and associated factors among elderly men: the Finnish cohorts of the Seven Countries Study. Age Ageing. 1998;27(1):41-7. doi: 10.1093/ ageing/27.1.41, PMID 9504365.

2. Krause NM, Jay GM. What do global self-rated health items measure? Med Care. 1994;32(9):930-42. doi: 10.1097/00005650-199409000-00004, PMID 8090045.

3. Jang Y, Poon LW, Kim SW, Shin B. Self-perception of aging and health among older adults in Korea. J Aging Stud. 2004;18(4):485-96. doi: 10.1016/j. jaging.2004.06.001.

4. Alok K, Sagaza H, Yadava KNS. Elderly: demographic profiles and related issues in rural Northern India. Paper presented in The 7th Asian/Ocean Reg Congress of Gerontology, during Nov. Vols. 24-28. Tokyo; 2003.

5. Vijayanunni. The graying population in India: 1991 census results. Res Dev J. 1997;3(3):3-12.

6. Yadava KNS, Yadava SS, Ron RE. Ageing and health hazards in rural North India. Health Popul Perspect Issues. 1996:) 19(1):1-18.

7. MurrayCJL, Yang G, Qiao X. Adult mortality: levels, trends and causes. In: Feachan, et al., editors The health of adults in the Developing World. Washington, DC: World Bank; 1992

8. Knodel J, Chayovan N. Family support and living arrangements of Thai elderly. Asia Pac Popul J. 1997;12(4):51-68. doi: 10.18356/2e4a0e5d-en, PMID 12293567.

9. Nair PS. The aged in rural India: A study of socio-economic and health profile. In: Singh, et al., editors Population transition in India. Vol. 2, Delhi: B.R. Publishing Corporation; 1998. p. 9.

10. Mostafa G, van Ginneken JK. Trends in and determinants of mortality in the elderly population of Matlab, Bangladesh. Soc Sci Med. 2000;50(6):763-71. doi: 10.1016/s0277-9536(99)00295-6. PMID 10695976.

11. Yadav, K.N.S, Yadav, Surender S and Roberts E. Ron (1996), Ageing and health hazards in rural north india, Health \& population- Perspectives and issues, 19(1):1-18.

Cite this Article : Srivastava A, Singh P, Pandey D, Srivastava S, Hasan SN. Socio-Demographic Status and Self Rated Health Condition of the Elderly in Eastern Uttar Pradesh. J. Clin. Res. Applied Med. 2021;1(1):11-7. 